\title{
The effect of excess dietary manganese on uninfected and Ascaridia galli infected chicks
}

\author{
M. Gabrashanska ${ }^{1 *}$, S. Tepavitcharova ${ }^{2}$, C. Balarew ${ }^{2}$, \\ M.M. Galvez-Morros ${ }^{3}$ and P. Arambarri ${ }^{4}$ \\ ${ }^{1}$ Institute of Experimental Pathology and Parasitology, \\ ${ }^{2}$ Institute of General and Inorganic Chemistry, \\ Bulgarian Academy of Sciences, 1040 Sofia, Bulgaria: \\ ${ }^{3}$ Universidad Complutense de Madrid, Facultad Veterinaria, \\ Departamento de Patologia Animal II, 28040 Madrid, Spain: \\ ${ }^{4}$ Instituo de Recursos Naturales y Agrobiologia de Sevilla, \\ 41080 Sevilla, Spain
}

\begin{abstract}
The effect of dietary manganese from two different sources on chicks (uninfected and infected with Ascaridia galli) was studied. Chick diet was supplemented with $0.9 \mathrm{~g} \mathrm{Mn}^{2+} \mathrm{kg}^{-1}$ food either in the form of $\mathrm{MnSO}_{4} \cdot \mathrm{H}_{2} \mathrm{O}$ or 2Gly. $\mathrm{MnCl}_{2} \cdot 2 \mathrm{H}_{2} \mathrm{O}$ for 20 days. Chicks were divided into six groups: group 0 , control; group 1, control $+\mathrm{MnSO}_{4} \cdot \mathrm{H}_{2} \mathrm{O}$; group 2, control $+2 \mathrm{Gly} \cdot \mathrm{MnCl}_{2} \cdot 2 \mathrm{H}_{2} \mathrm{O}$; group 3, infected with $A$. galli; group 4, infected with A. galli $+\mathrm{MnSO}_{4} \cdot \mathrm{H}_{2} \mathrm{O}$; and group 5, infected with $A$. galli +2 Gly. $\mathrm{MnCl}_{2} \cdot 2 \mathrm{H}_{2} \mathrm{O}$. Body weight, mortality, worm burden, and liver manganese content were investigated. Excess dietary manganese increased weights and manganese level, but mortality and worm burden were unaffected. A greater bioavailability of manganese from 2Gly. $\mathrm{MnCl}_{2} \cdot 2 \mathrm{H}_{2} \mathrm{O}$ was established.
\end{abstract}

\section{Introduction}

The nutritional importance of manganese for chicks has previously been investigated by Watson et al. (1970). Birds are more sensitive to manganese deficiency than mammals (Berenschtein, 1968).

Ascaridiosis is a widespread helminthosis in birds, influencing slow growth, deformation of the skeleton and changes in reproductive function. These disturbances are connected with metabolic disorders, especially with manganese deficiency (Balayan, 1982; Gabrashanska et al., 1986, 1987) and inorganic manganese supplements are added to conventional poultry diets to meet the manganese requirements. Recent information has shown that manganese, forming chelates or complexes with protein or single amino acids, has resulted in similar

*Author for correspondence.

Fax: +3592710107. or superior effects compared with manganese from inorganic sources (Black et al., 1984; Smith et al., 1995). The latter authors also showed that the biological availability of manganese from $\mathrm{Mn}^{2+} /$ protein is higher than that from $\mathrm{MnSO}_{4} \cdot \mathrm{H}_{2} \mathrm{O}$ and $\mathrm{MnO}$ in healthy chicks (Smith et al., 1995).

The aim of the present investigation is to estimate the effect of dietary excess manganese from two different sources $\left(\mathrm{MnSO}_{4} \cdot \mathrm{H}_{2} \mathrm{O}\right.$ and $\left.2 \mathrm{Gly} \cdot \mathrm{MnCl}_{2} \cdot 2 \mathrm{H}_{2} \mathrm{O}\right)$ on chicks, uninfected and infected with Ascaridia galli, based on changes in body weight, mortality, worm burden and manganese content of the liver.

\section{Materials and methods}

Two different sources of manganese $\left(\mathrm{MnSO}_{4} \cdot \mathrm{H}_{2} \mathrm{O}\right.$ and 2Gly. $\mathrm{MnCl}_{2} \cdot 2 \mathrm{H}_{2} \mathrm{O}$ ) were used to supplement manganese into the chicks diet. $\mathrm{MnSO}_{4} \cdot \mathrm{H}_{2} \mathrm{O}$ was a commercial grade p.a. reagent (Merck). $2 \mathrm{Gly} \cdot \mathrm{MnCl}_{2} \cdot 2 \mathrm{H}_{2} \mathrm{O}$ was synthesized 
Table 1. Body weights (g) of chicks uninfected and infected with Ascaridia galli, and treated and untreated with manganese compounds.

\begin{tabular}{lccccccc}
\hline Chick groups* $^{*}$ & Day 1 & Day 10 & Day 20 & Day 30 & Day 40 & Day 50 \\
\hline 0 & $109.32 \pm 28.32$ & $297.05 \pm 34.11$ & $445.90 \pm 74.98$ & $548.51 \pm 91.75$ & $623.40 \pm 112.00$ & $710.12 \pm 37.57$ & $891.93 \pm 70.76$ \\
1 & $109.32 \pm 28.32$ & $305.98 \pm 59.30$ & $461.54 \pm 128.99$ & $583.00 \pm 26.77$ & $691.76 \pm 51.45$ & $806.64 \pm 67.03$ & $936.90 \pm 112.08$ \\
$P_{0,1}$ & - & $>0.1$ & $>0.1$ & $<0.05$ & $<0.01$ & $<0.001$ & $>0.1$ \\
2 & $109.32 \pm 28.32$ & $296.78 \pm 10.57$ & $470.93 \pm 32.02$ & $595.33 \pm 82.16$ & $686.18 \pm 44.06$ & $846.47 \pm 43.51$ & $994.30 \pm 105.72$ \\
$P_{0,2}$ & - & $>0.1$ & $<0.1$ & $>0.1$ & $<0.01$ & $<0.001$ & $<0.01$ \\
$P_{1,2}$ & - & $>0.1$ & $>0.1$ & $>0.1$ & $>0.1$ & $<0.1$ & $<0.1$ \\
3 & $109.32 \pm 28.32$ & $289.07 \pm 14.90$ & $372.99 \pm 22.90$ & $513.00 \pm 60.89$ & $595.86 \pm 58.52$ & $610.54 \pm 90.07$ & $695.14 \pm 47.25$ \\
$P_{0,3}$ & - & $>0.1$ & $<0.1$ & $>0.1$ & $>0.1$ & $<0.001$ & $<0.001$ \\
4 & $109.32 \pm 28.32$ & $304.26 \pm 29.30$ & $374.51 \pm 32.66$ & $515.54 \pm 83.66$ & $605.02 \pm 55.99$ & $762.46 \pm 106.95$ & $875.97 \pm 44.62$ \\
$P_{3,4}$ & - & $>0.1$ & $>0.1$ & $>0.1$ & $>0.1$ & $<0.1$ & $<0.01$ \\
5 & $109.32 \pm 28.32$ & $300.66 \pm 18.04$ & $343.51 \pm 37.88$ & $529.34 \pm 108.41$ & $612.38 \pm 48.41$ & $728.95 \pm 140.21$ & $899.82 \pm 151.07$ \\
$P_{3,5}$ & - & $>0.1$ & $>0.1$ & $>0.1$ & $>0.1$ & $<0.01$ & $<0.001$ \\
$P_{4,5}$ & - & $>0.1$ & $>0.1$ & $>0.1$ & $>0.1$ & $>0.1$ & $>0.1$ \\
\hline
\end{tabular}

*See text for key to groups of chicks.

by Balarew et al. (1994), under conditions established by studying the Gly. $\mathrm{MnCl}_{2} \cdot 2 \mathrm{H}_{2} \mathrm{O}$ system at $25^{\circ} \mathrm{C}$ using the method of isothermal decrease of the supersaturation (Balarew et al., 1970). Two compounds crystallize in this system - $2 \mathrm{Gly}_{\mathrm{MnCl}} \cdot 2 \mathrm{H}_{2} \mathrm{O}$ and Gly. $\mathrm{MnCl}_{2} \cdot 2 \mathrm{H}_{2} \mathrm{O}$, although the former was preferred in this study, because of its higher $\alpha$-amino acetic acid (Gly) content. Thermal investigations of $2 \mathrm{Gly} \cdot \mathrm{MnCl}_{2} \cdot 2 \mathrm{H}_{2} \mathrm{O}$ show that dehydration occurs at $35^{\circ} \mathrm{C}$ resulting in the production of an anhydrous compound.

One-day-old male chicks, Hisex breed were weighed and divided into six groups of 30: group 0, control (uninfected and untreated); group 1, uninfected and treated with $\mathrm{MnSO}_{4} \cdot \mathrm{H}_{2} \mathrm{O}$; group 2, uninfected and treated with 2Gly. $\mathrm{MnCl}_{2} \cdot 2 \mathrm{H}_{2} \mathrm{O}$; group 3, experimentally infected with A. galli; group 4, infected and treated with $\mathrm{MnSO}_{4} \cdot \mathrm{H}_{2} \mathrm{O}$; and group 5, infected and treated with 2Gly. $\mathrm{MnCl}_{2} \cdot 2 \mathrm{H}_{2} \mathrm{O}$. The chicks were placed on pine shavings in $1.2 \times 3.6 \mathrm{~m}$ pens which were grouped randomly. There were six blocks of one treatment each. Chicks were maintained on a $24 \mathrm{~h}$ constant light schedule in heated, thermostatically controlled, stainless steel starter batteries with raised wire floors. Feeders and water containers were also of stainless steel construction to minimize environmental manganese contamination. All chicks were fed on a corn-soybean meat diet containing $157 \mathrm{mg} \mathrm{Mn}^{2+} \mathrm{kg}^{-1}$ food, formulated to meet the nutrient requirements of the growing chicks (National Research Council, 1994). The chicks from groups 1, 2, 4 and 5 received an additional $0.9 \mathrm{~g} \mathrm{Mn}^{2+} \mathrm{kg}^{-1}$ food either in the form of $\mathrm{MnSO}_{4} \cdot \mathrm{H}_{2} \mathrm{O}$ or $2 \mathrm{Gly} \cdot \mathrm{MnCl}_{2} \cdot 2 \mathrm{H}_{2} \mathrm{O}$. The manganese compounds were given for 20 days, starting 5 days postinfection (p.i.). Chicks from groups 3,4 and 5 were each infected experimentally with 450 embryonated eggs at 14 days posthatching, as described by Permin et al. (1997).

Chicks were allowed access to food and water ad libitum. Chicks were killed after 60 days and their alimentary tracts opened in a longitudinal section from the gizzard to the cloaca. The contents were washed into a $100 \mu \mathrm{m}$ sieve, transferred to a Petri dish, examined for the presence of immature and mature A. galli under a microscope and the number of worms counted. Liver samples were dried at $100^{\circ} \mathrm{C}$ for $24 \mathrm{~h}$, weighed, ground and then burned slowly in a muffle furnace up to $480^{\circ} \mathrm{C}$ for $48 \mathrm{~h}$. The ashes obtained were treated with a mixture of concentrated $\mathrm{H}_{2} \mathrm{SO}_{4}$ and $\mathrm{HNO}_{3}$ (1:5) in a sand bath and the wet residues were dissolved in $1 \mathrm{M} \mathrm{HCl}$. The determination of $\mathrm{Mn}^{2+}$ was made using an atomic absorption spectrophotometer (Anon., 1982). Body weight and mortality rates were determined at 1, 10, 20, $30,40,50$ and 60 days. The data were tested using analysis of variance (Steel \& Torrie, 1980) and Duncan's new multiple range test (1955) was used to separate significant differences between means.

\section{Results and discussion}

The addition of manganese to the diet increased the body weight of chicks and this increase is greater when manganese is added in the form of $2 \mathrm{Gly}^{\mathrm{M}} \mathrm{MnCl}_{2} \cdot 2 \mathrm{H}_{2} \mathrm{O}$ (group 2) compared with the inorganic source $\mathrm{MnSO}_{4} \cdot \mathrm{H}_{2} \mathrm{O}$ (group 1) (table 1). Increases in weight appear in both groups after the 20th day and are higher between days 40 and 50 . However, at the end of the experiment the body weight of chicks supplemented with $\mathrm{MnSO}_{4} \cdot \mathrm{H}_{2} \mathrm{O}$ levelled off with respect to controls $\left(P_{0,1}<\right.$ 0.1 ), while that of chicks supplemented with the 2Gly. $\mathrm{MnCl}_{2} \cdot 2 \mathrm{H}_{2} \mathrm{O}$ (group 2) was higher compared with controls $\left(P_{0,2}<0.1\right)$. Chicks from group 2 were heavier than those from group $1\left(P_{1,2}<0.01\right)$.

A loss in body weight caused by $A$. galli infections, which is apparent by day $30\left(P_{0,3}<0.001\right)$, is compensated by the addition of manganese. Treatment of infected chicks with $\mathrm{MnSO}_{4} \cdot \mathrm{H}_{2} \mathrm{O}$ led to weight increases after day $40\left(P_{3,4}<0.01\right.$ resp.). Significant growth of infected chicks treated with $2 \mathrm{Gly} \cdot \mathrm{MnCl}_{2} \cdot 2 \mathrm{H}_{2} \mathrm{O}$ was also evident by 40 days $\left(P_{3,5}<0.01\right)$. Significant differences between the weight of infected chicks treated with $\mathrm{MnSO}_{4} \cdot \mathrm{H}_{2} \mathrm{O}$ and 2Gly. $\mathrm{MnCl}_{2} \cdot 2 \mathrm{H}_{2} \mathrm{O}$ were not established $(P>0.1)$.

The addition of manganese did not significantly reduce mortality levels in health control chicks. Ascaridia galli infections increased host mortality by $40 \%$ compared with uninfected chicks (table 2). Supplementation with $\mathrm{MnSO}_{4} \cdot \mathrm{H}_{2} \mathrm{O}$ did not influence the mortality rate in infected chicks $\left(P_{3,4}>0.1\right)$ although the presence of $2 \mathrm{Gly} \cdot \mathrm{MnCl}_{2} \cdot 2 \mathrm{H}_{2} \mathrm{O}$ reduced the rate $\left(P_{3,5}<0.1\right)$. There were no statistical differences between the chicks from groups 4 and $5\left(P_{4,5}>0.1\right)$. 
Table 2. Number of chicks infected and uninfected with Ascaridia galli and treated and untreated with manganese compounds.

\begin{tabular}{|c|c|c|c|c|c|c|c|c|}
\hline Chick groups* & Day 1 & Day 10 & Day 20 & Day 30 & Day 40 & Day 50 & Day 60 & Mortality (\%) \\
\hline 0 & 30 & 29 & 29 & 29 & 28 & 28 & 28 & 6.7 \\
\hline 1 & 30 & 30 & 30 & 30 & 30 & 30 & 30 & - \\
\hline 2 & 30 & 30 & 30 & 30 & 29 & 29 & 29 & 3.3 \\
\hline$P_{0,3}$ & - & - & $<0.1$ & $<0.01$ & $<0.01$ & $<0.01$ & $<0.01$ & $<0.01$ \\
\hline 4 & 30 & 28 & 21 & 21 & 20 & 19 & 19 & 36.7 \\
\hline$P_{3,4}$ & - & $>0.1$ & $>0.1$ & $>0.1$ & $>0.1$ & $>0.1$ & $>0.1$ & $>0.1$ \\
\hline$P_{4,5}^{3,3}$ & - & - & $>0.1$ & $>0.1$ & $>0.1$ & $>0.1$ & $>0.1$ & $>0.1$ \\
\hline
\end{tabular}

*See text for key to groups of chicks.

Worm burdens in chicks on day 55 are presented in table 3 . The highest number of $A$. galli was found in group 5, and the lowest in group 3 . Differences between worn burdens in chicks receiving $\mathrm{MnSO}_{4} \cdot \mathrm{H}_{2} \mathrm{O}$ and 2Gly. $\mathrm{MnCl}_{2} \cdot 2 \mathrm{H}_{2} \mathrm{O}$, and those untreated was significant $\left(P_{3,4}<0.1\right.$ and $P_{3,5}<0.1$ respectively). Chicks receiving $2 \mathrm{Gly} \cdot \mathrm{MnCl}_{2} \cdot 2 \mathrm{H}_{2} \mathrm{O}$ showed the greatest increase in worm burdens.

The manganese concentration in the liver is shown in table 4. Supplementation with manganese markedly enhanced manganese deposition in the livers of healthy chicks $P_{0,1}<0.001$ (groups 1 and 2). Ascaridia galli infection lowered manganese levels in the liver during the acute phase of infection $\left(P_{0,3}<0.01\right)$. Infected chicks treated with 2Gly. $\mathrm{MnCl}_{2} \cdot 2 \mathrm{H}_{2} \mathrm{O}$ had higher levels of manganese than those treated with $\mathrm{MnSO}_{4} \cdot \mathrm{H}_{2} \mathrm{O}\left(P_{4,5}<\right.$ 0.1). A significant 2Gly. $\mathrm{MnCl}_{2} \cdot 2 \mathrm{H}_{2} \mathrm{O} \times$ A. galli infection interaction was observed in the manganese liver concentration. Manganese losses in infected chicks were restored by manganese supplementation. Uninfected and infected chicks treated with manganese compounds in pharmacological doses showed an improvement in growth and their manganese concentrations were restored, without any toxic signs. The addition of $2 \mathrm{Gly} \cdot \mathrm{MnCl}_{2} \cdot 2 \mathrm{H}_{2} \mathrm{O}$ had a greater effect on chick growth and on the manganese content of the liver than that of $\mathrm{MnSO}_{4} \cdot \mathrm{H}_{2} \mathrm{O}$. The addition of $2 \mathrm{Gly} \cdot \mathrm{MnCl}_{2} \cdot 2 \mathrm{H}_{2} \mathrm{O}$ to the diet to achieve a pharmacological dose level of manganese would make glycine available and this is likely to contribute to the greater weight gains recorded.

The simultaneous introduction of two biogenic elements such as manganese and glycine may stimulate the growth of chicks. The Mn-Gly complex may prevent

Table 3. Worn burdens of Ascaridia galli at day 55 post infection.

\begin{tabular}{lc}
\hline Chick groups $^{*}$ & Mean worm number \\
\hline 0 & - \\
1 & - \\
2 & - \\
3 & $45.72 \pm 2.18$ \\
4 & $69.45 \pm 3.22$ \\
5 & $80.50 \pm 1.97$ \\
$P_{3,4}$ & $<0.01$ \\
$P_{3,5}$ & $<0.001$ \\
$P_{4,5}$ & $<0.1$ \\
\hline
\end{tabular}

*See text for key to groups of chicks. manganese from binding to other ligands, which normally make it unavailable. According to Kratzer \& Vohra (1986), complexes of metals with amino acids or proteins improve bioavailability of minerals. Metal complexes are preferred by absorption sites in the intestine, compared with pure metal ions (Smith et al., 1995). The greater solubility of $2 \mathrm{Gly} \cdot \mathrm{MnCl}_{2} \cdot 2 \mathrm{H}_{2} \mathrm{O}$ (57.5 mass \%) compared with that of $\mathrm{MnSO}_{4} \cdot \mathrm{H}_{2} \mathrm{O}$ (39.3 mass \%) may support the manganese absorption from the Mn-Gly complex.

Higher manganese and glycine levels in the intestinal lumen may lead to their greater availability for the parasites. In the present study, worm growth and number were stimulated by excess manganese and glycine. The higher worm burdens in treated chicks, however did not influence host mortality or body weight.

Our results, suggesting a more effective action by 2Gly. $\mathrm{MnCl}_{2} \cdot 2 \mathrm{H}_{2} \mathrm{O}$ compared with $\mathrm{MnSO}_{4} \cdot \mathrm{H}_{2} \mathrm{O}$, are consistent with the data of Smith et al. (1995) concerning manganese, and also of Aoyagi \& Baker (1993) concerning $\mathrm{Zn}^{2+}$ and $\mathrm{Cu}^{2+}$. They indicate that $\mathrm{Mn}^{2+}, \mathrm{Zn}^{2+}, \mathrm{Cu}^{2+}$ from $\mathrm{Mn}$-protein, $\mathrm{Zn}$-Lys, $\mathrm{Cu}$-Lys improved the bioavailability of these trace elements in healthy chicks more so than the conventional inorganic sources.

Our studies have compared the bioefficacy of Mn-Gly complex with that of $\mathrm{MnSO}_{4} \cdot \mathrm{H}_{2} \mathrm{O}$ in healthy and infected chicks and have shown that $2 \mathrm{Gly} \cdot \mathrm{MnCl}_{2} \cdot 2 \mathrm{H}_{2} \mathrm{O}$ may prove a more efficacious supplement, based on body weight

Table 4. Manganese concentration in chick liver, uninfected and infected with Ascaridia galli, and treated and untreated with manganese compounds.

\begin{tabular}{lc}
\hline Chick groups & $\mathrm{Mn}^{2+}\left(\mu \mathrm{g} \mathrm{g}^{-1}\right.$ dry weight $)$ \\
\hline 0 & $5.89 \pm 1.12$ \\
1 & $10.22 \pm 3.27$ \\
$P_{0,1}$ & $<0.001$ \\
2 & $11.18 \pm 2.25$ \\
$P_{0,2}$ & $<0.001$ \\
$P_{1,2}$ & $>0.1$ \\
3 & $3.91 \pm 0.49$ \\
$P_{0,3}$ & $<0.01$ \\
4 & $5.72 \pm 0.13$ \\
$P_{3,4}$ & $<0.001$ \\
5 & $8.95 \pm 1.18$ \\
$P_{3,5}$ & $<0.001$ \\
$P_{4,5}$ & $<0.01$ \\
\hline
\end{tabular}

*See text for key to groups of chicks. 
gain and mortality levels in chicks infected with A. galli. Additional research is required to confirm whether this new compound should be one of the preferred sources of manganese for the treatment of chicks infected with A. galli.

\section{Acknowledgments}

Financial support of the Ministry of Education and Science, Project Ch-551 is gratefully acknowledged.

\section{References}

Anon. (1982) Analytical methods for atomic absorption spectrophotometry. Norwalk, Connecticut, Perkin-Elmer Corp.

Aoyagi, S. \& Baker, D. (1993) Nutritional evaluation of coppor-lysine and zinc-lysine complexes for chicks. Poultry Science 72, 165-171.

Balarew, C., Karaivanova, V. \& Ojkova, T. (1970) Beitrag zur Untersuchung der isomorphen und isodimorphen Einschlüsse in Kristallsalzen. III. Untersuchung der Systeme Zinksulfat-Kobaltsulfat-Wasser und Zinksulfat-Nickelsulfat-Wasser bei $25^{\circ} \mathrm{C}$. Communications of the Department of Chemistry, Bulgarian Academy of Sciences 3, 637-643.

Balarew, C., Spasov, V. \& Tepavitcharova, S. (1994) Pyroand ferroelectric properties of nGly. $\mathrm{MeCl}_{2} \cdot 2 \mathrm{H}_{2} \mathrm{O}(\mathrm{Me}=$ $\mathrm{Mn}, \mathrm{Co} ; \mathrm{n}=1,2)$. Ferroelectrics 158, 157-162.

Balayan, D.E. (1982) On the effect of helminthoses on the content of microelements (copper, molybdenum, manganese, iron, zinc) in tissues and organs of sheep. Zoological Papers, XVIII 46, 245-257 (in Russian).

Berenschtein, F. (1968) Micro elements, biological role and their importance for stock-breeding. pp. 45-180. Kiev, Urogaj.

Black, J., Ammerman, C., Henry, P. \& Miles, R. (1984) Biological availability of manganese sources and effect of high dietary manganese on tissue mineral composition of broiler-type chicks. Poultry Science 63, 1999-2006.

Duncan, D.B. (1955) Multiple range and multiple F tests. Biometrics 11, 1-42.

Gabrashanska, M., Daskalova, A. \& Ossikowski, E. (1986) Veründerungen im Status der Spurenelemente von Küken bei Experimenteller Infection mit. Ascaridia galli Monatschefte für Veterinaermedizin 41, 446-450.

Gabrashanska, M., Daskalova, A. \& Ossikowski, E. (1987) Comparative investigations on the microelement status of Ascaridia galli (Schrank, 1788; Freeborn, 1923) and its host (Gallus gallus). Helminthologia 24, 209-214.

Kratzer, F. \& Vohra, P. (1986) Chelates in nutrition. pp. 145207. Boca Raton, CRC Press Inc.

National Research Council (1994) Nutrient requirements of poultry. 9th edn. Washington, D.C., National Academy Press.

Permin, A., Pearman, M., Nansen, P., Bisgaard, M. \& Frandsen, F. (1997) An investigation on different media for embryonation of Ascaridia galli eggs. Helminthologia 34, 75-79.

Smith, M., Sherman, Y., Miller, L., Robbins, K. \& Halley, J. (1995) Relative biological availability of manganese from manganese proteinate, manganese sulfate and manganese monoxide in broilers reared in elevated temperatures. Poultry Science 74, 702-707.

Steel, R. \& Torrie, J. (1980) Principles and procedures in statistics: a biometrical approach. 2nd edn. New York, McGraw-Hill Book Co.

Watson, H.T., Ammerman, C., Miller, M.S. \& Harms, R.H. (1970) Biological assay of inorganic manganese for chicks. Poultry Science 49, 1548-1554.

(Accepted 9 June 1999)

(C) CAB International, 1999 